\title{
Identification of argininosuccinate lyase as a hypoxia-responsive gene in rat hepatocytes
}

\author{
María Ujue Latasa, M Victoria Carretero, Elena R García-Trevıjano, Luıs Torres, José M Mato and \\ Matías A Avila \\ Unidad de Hepatologia y Terapia Genica, Departamento de Medicina Interna, Facultad de Medictna, Universidad de Navarra, Pamplona, Spain
}

Background/Aims: The differential oxygenation of periportal and perivenous hepatocytes has been demonstrated as a major determinant in the zonated expression of certain metabolic pathways in the liver. We have searched for novel genes whose expression could be modulated by hypoxia in cultured rat hepatocytes. Methods: Primary cultures of rat hepatocytes were incubated under normoxic (21\% oxygen) or hypoxic (3\% oxygen) conditions for $6 \mathrm{~h}$. Differences in gene expression under both conditions were analyzed using the technique of differential display by means of PCR. Results: We have identified the enzyme argininosuccinate lyase (ASL) as being downregulated by hypoxia. ASL is a cytosolic protein which participates in urea metabolism. ASL expression was time-depend-

$\mathrm{T}$ HE LIVER possesses an enormous and diverse catalytic potential which is mainly met by the parenchymal cell In spite of the histological uniformity of this organ, functional differences have been reported for parenchymal cells located in the periportal and the pericentral or perivenous areas, leading to the concept of the metabolic zonation of the liver (1) This zonation of the liver includes most of the key functions of the organ, such as oxidative and carbohydrate metabolısm, amino acid metabolısm and ammonia detoxification, bile formation, plasma protein synthesis and xenobiotic detoxification (reviewed in 2) Numerous results indicate that zonation of liver tissue is attained by the differential expression of key enzymes involved in the metabolic pathways mentioned above $(1,2)$

Received 13 Junuary revised 11 Aprtl accepted 2 May 2000

Correspondence José M Mato, Unidad de Hepatología y Terapıa Génıca, Departamento de Medicina Interna, Ed1ficıo Los Castaños, Facultad de Medıcına, Unıversıdad de Navarra, 31008 Pamplona, Spain Fax 34948425677 Tel 34948425678 e-ma1l jmmato@unaves ently reduced in hypoxia. Hypoxia modulated the responses of this gene to the two main hormonal signals which induce ASL mRNA: glucocorticoids and cAMP. ASL mRNA levels decreased in response to ATP-reducing agents. $\mathrm{CoCl}_{2}$ mimicked the effect of hypoxia, suggesting the implication of a hemoprotein in this response. Hypoxia did not affect ASL mRNA stability, indicating that this effect occurs at the transcriptional level.

Conclusions: Our observations suggest that differences in oxygen levels across the hepatic parenchyma could participate in the zonated expression of ASL.

Key words: Argininosuccinate lyase; Gene expression; Hypoxia; Liver.

Many of the brological signals that modulate the gene expression pattern of the distinctly located hepatic cells are generated by a gradient in the concentration of oxygen, hormones, substrates and blood-borne products circulating from the periportal to the perivenous compartments Oxygen tension in the perivenous area is reduced to about half of that found in the periportal area (35 vs $65 \mathrm{mmHg}$ ), and has been identified as one of the major determinants in the zonal expression of carbohydrate-metabolizing enzymes (2)

Apart from playing a role in the metabolic zonation of the liver, regulation of gene expression by oxygen levels may represent a more general adaptive mechan1sm of the cell and the organism to low oxygen supply This is evidenced by the nature of the different hypoxia-responsive genes so far identified, which include erythroporetın, vascular endothelial growth factor, aldolase A, tyrosine hydroxylase, the glucose transporter glutl gene (3-7) and hypoxia-downregulated genes such as methionıne adenosyltransferase (8)

In order to gain more insight into the genetic mechanısms behind this adaptation, we have searched for 
genes whose expression might be modulated by hypoxia in cultured rat hepatocytes Our analysis employing the technique of differential display by means of polymerase chain reaction (PCR) (DDPCR) (9) has allowed us now to identify argınınosuccinate lyase (EC 4321 , ASL) as a novel hypoxia-regulated gene, which is downregulated by low oxygen levels ASL is d cytoplasmic enzyme highly expressed in the adult liver, as compared to other tissues, where it plays a role in urea synthesis (10), a metabolic pathwdy differentidlly expressed across the periportal and perivenous areas (2) We have also addressed the influence of hypoxid on the hormonal regulation of ASL expression in cultured rat hepatocytes as well as the mechanısms behind this effect

\section{Materials and Methods}

Materials

All chemicals were of reagent grade and obtained from commercial suppliers Collagenase, actmomycin D, catalase and restriction enzymes were from Boehringer Mannherm (Mannheim, Germany) Tr1amcinolone, $\mathrm{CoCl}_{2}$ desferrioxamine forskolın, and menadıone were from Sigma (St Louls, MO. USA)

\section{Isolation and culture of rat hepatocytes \\ Liver parenchymal cells were isolated from male Wistur rats (200 250 $\mathrm{g}$ of weight) by collagenase perfusion, as described ( 8 ) Cells were plated and cultured as described (8) Cells were maintained at $37^{\circ} \mathrm{C}$ in a humidified incubator contaning $21 \%$ oxygen and $5 \% \mathrm{CO}_{2}$ in arr (normoxic conditions) Hypoxic conditions were attamed by exposure to $3 \%$ oxygen and $5 \% \mathrm{CO}_{2}$ with the balance as nitrogen in a humidi- fied Billups-Rothenberg Modulai Incubation Chamber (MIC-101) (Del mar, CA, (ISA) at $37^{\circ} \mathrm{C}$ (8) Cell vlability was medsured by try- pan blue exclusion, no significant differences were observed between normoxic and hypoxic cultures at any culture time tested}

Differential display by means of $P C R$ analysis

DDPCR was performed on total cellular RNA, ssolated as described (11), after DNAsel treatment, using oligo(dT) anchored prumers with Hieroglyph mRNA Profile Kit (Genomyx Beckman Instruments, Fullerton, CA, USA) ds described $(9,12)$ Nucleotide sequence homology sedrch andlysis of the EMBL (13) dnd GeneBank (14) databases were performed using the program FASTA (15)

RNA isolation and Northern blot analysis

Total hepatocyte RNA was isolated by the guanidinium thiocyanate method (16) Electrophoresis of RNA, gel blotting, prehybridization and hybridization of membranes were carried out as described $(11,12)$ The glutl cDNA probe was the generous gift of Dr Antonio Zorzano (Unversidad de Baicelond, Barcelona, Spain) The probes were labeled with $\left[\alpha-{ }^{32} \mathrm{P}\right]$ dCTP (Amersham, Little Chalfont, UK) using the Megaprime DNA labeling system (Amersham) Equal loading of the gels was assessed by hybridization with an $18 \mathrm{~S}$ ribosomal RNA probe Quantitation was performed by scanning densitometry of the X-ray films

When the effect of actinomycin D on the regulation of ASL mRNA levels by hypoxid was studied, hepatocytes were cultured in the presence of $1 \mu \mathrm{M}$ triamcinolone to induce ASL expression for $10 \mathrm{~h}$ then actinomycin D $(5 \mu \mathrm{g} / \mathrm{ml})$ was added and after $1 \mathrm{~h}$ cells were further mcubated under normoxic or hypoxic conditions for the indicated pertods of time

Measurement of ASL actovit

ASL activity was measured on hepatocyte homogenates as described by Tomlison \& Westall (17) Results are expressed as micromoles of urea formed per hour (units) per milhigram of protein Pioten content in homogenates was measured as described (18)

Immunoblot analysis

Cultured hepatocytes were lysed as described (11) Total protem was determined in the extracts as described (18) Electrophoresis and electroblotting were carried out as described (12) Immunodetection of the glucocorticold receptor (GR) was performed using d polyclonal ant1-GR antiserum (Santa Cruz Biotechnology Santa Cruz CA. USA) and a horserddish peroxidase-conjugated secondaly antibody Blots wele developed by enhanced chemoluminescence according to the manufacturer's instructions (Dupont Boston MA, USA)

Statrstir.s

Ddta dre means \pm SEM of at least four independent experiments performed in duplicate Statistical ignificance was estimated with Student s $t$-test $A p$-valuc of $<005$ was considered significant

\section{Results}

Identification of ASL as a hyporia-responstve gene DDPCR analysis was carried out on 1 dt hepatocytes cultured for $6 \mathrm{~h}$ in normoxia or hypoxia Several bands were differentially expressed in the two culture conditions One of the bands selected for andlysis, which was downregulated in the hypoxic cells (F1g 1A) was excised from the gel, amplified and sequenced Sequencing of $032 \mathrm{~kb}$ of the total $06 \mathrm{~kb}$ of this clone revealed a $100 \%$ identity to rat ASL cDNA (nucleotudes 2101 to 2422) (19), and could hybridize a $24 \mathrm{~kb}$ mRNA in total cellular RNA from hepatocytes (Fig 1A) The band detected using Northern analysis corresponded in size to that reported for the ASL transcript in rat liver (20), and showed a $60 \%$ reduction during hypoxia Hybridization with a cDNA probe for the glutl gene, a well-known hypoxia-responsive gene which is induced by this condition (7), was performed as a control As shown in Fig 1B, GLUT-1 mRNA showed a sharp increase (6-fold after $6 \mathrm{~h}$ of treatment) during hypoxid

We next performed a time course experiment in order to further characterize ASL mRNA response to hypoxia As shown in Fig $1 \mathrm{~B}$ d reduction in cellular ASL mRNA was detected after $3 \mathrm{~h}$ of incubation under hypoxia, and was even more pronounced at 12 $h$ of incubation The concomitant induction of GLUT1 mRNA is also shown As repoited for other genes which are highly expressed in liver $(8,21)$, ASL mRNA levels in normoxia decreased with time in culture, however, the effect of hypoxid was still evident even after longer incubations (up to $17 \mathrm{~h}$, data not shown)

We also medsured ASL enzymatic activity in hepatocytes maintained in normoxia and hypoxia Our results indicate that after prolonged exposure to hypoxia (17 h) ASL activity remained unchanged ( $021 \pm 002 \mu \mathrm{mol} /$ $\mathrm{h} / \mathrm{mg}$ of piotein in normoxid is $019 \pm 001 \mu \mathrm{mol} / \mathrm{h} / \mathrm{mg}$ of protein in hypoxia) 


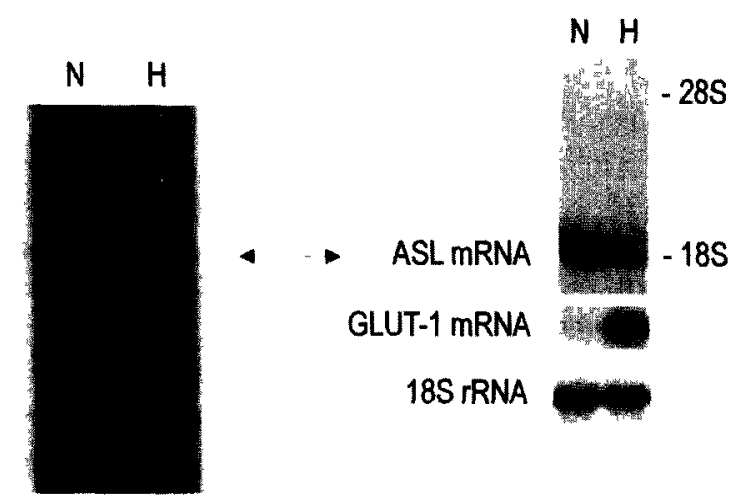

B
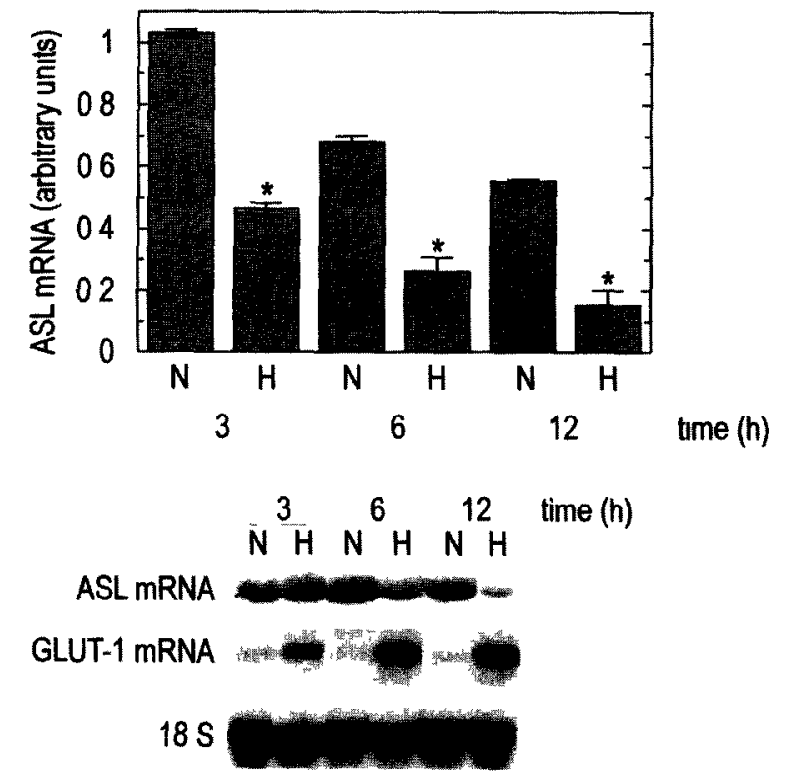

Fig 1 Detection of differentıal gene expression by hypoxia in isolated rat hepatocytes by differential $m R N A$ display analysis $A$ Sequencing gel electrophoresis of PCR ampl- fied cDNAs performed in duplicates, from normoxic $(N)$ and hypoxic $(H)$ cultures $A$ differentially displayed fragment (arrow) was detected, isolated, sequenced and tdenttfied as a $06 \mathrm{~kb}$ fragment of $A S L c D N A$ The right panel shows a Northern blot analysis of total RNA from normoxic $(N)$ and hypoxic $(H)$ rat hepatocytes performed with ASL cDNA fragment This assay confirmed its differential expression between normoxic and hypoxic cultures Induction of GLUT-1 mRNA expression by hypoxia is also shown Hybridization with a probe for $18 \mathrm{~S} r R N A$ was performed as loading control $B$ Time-course of the response of ASL to hypoxia in cultured rat hepatocytes Asterisks indicate $\mathrm{p}<005$ with respect to normoxic controls Lower panel shows a representative Northern blot The ttme-dependent induction of GLUT-1 mRNA by hypoxia is also shown Hybridization with a probe for the 18 S rRNA was performed as loading control

Hypoxia modulates ASL responses to glucocortıcotds and $c A M P$

Glucocorticoids and glucagon have been shown to upregulate ASL mRNA in rat liver and cultured hepato- cytes, and their effect is cumulative when added together (10) We have tested whether hypoxia could modulate the effect of both hormones on ASL expression As shown in Fig 2, when hepatocytes were treated for $6 \mathrm{~h}$ with triamcinolone $(1 \mu \mathrm{M})$ or the cAMP generating agent forskolin $(10 \mu \mathrm{M})$, ASL mRNA levels were induced (6-fold and 5-fold, respectively, over control levels) As described, the effect of both agents was cumulative when used in combination (12-fold induction) When these treatments were performed in hypoxic conditions the effects of triamcinolone and forskolin, alone or in combination, were partially prevented In order to test whether hypoxia could compromise the effect of glucocorticolds on ASL expression through the impairment of glucocorticold receptor (GR) expression, we analyzed the levels of GR in hepatocytes kept under normoxic or hypoxic conditions for $6 \mathrm{~h}$ in culture medium without triamcinolone As shown in Fig 3, GR protein levels were upregulated in hypoxia

\section{Hypoxia sensing and signaling in $A S L m R N A$ regulation}

Inhibition of oxidative phosphorylation and reduction of ATP levels are observed in hepatocytes exposed to

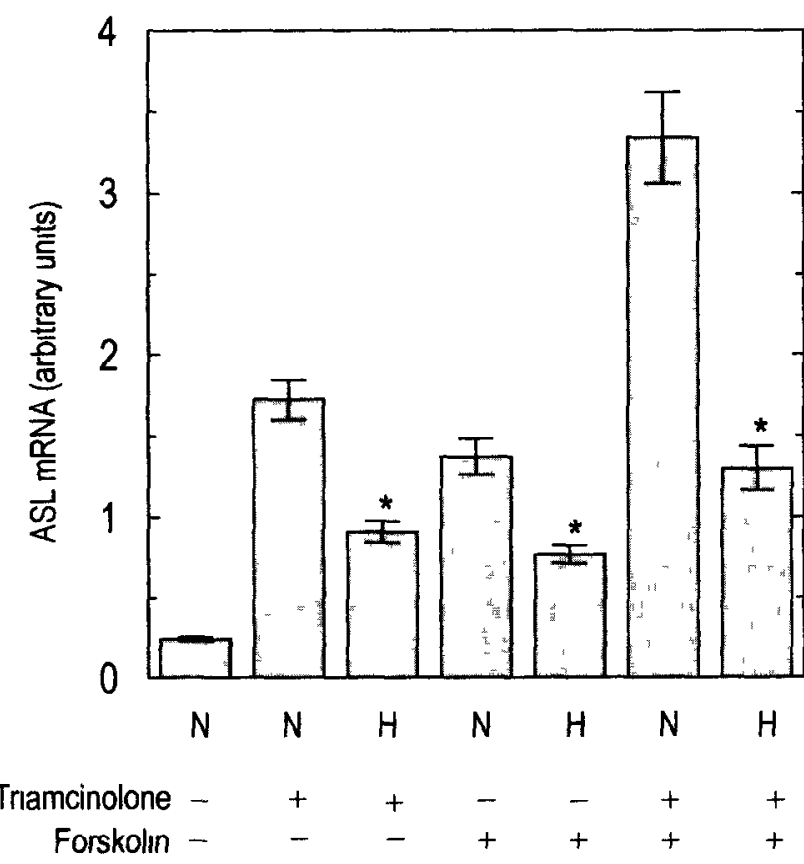

Fig 2 Modulation by hypoxia of ASL response to glucocortlcolds and the CAMP tnductng agent forskolin Hepatocytes were maintained in normoxic $(N)$ or hypoxic $(H)$ conditions for $6 \mathrm{~h}$ in the presence or absence of tramcinolone $(1 \mu M)$, forskoln $(10 \mu M)$ or both, and then $A S L$ $m R N A$ was quantitated by Northern blotting Astertsks indicate $\mathrm{p}<005$ with respect to normoxic controls 


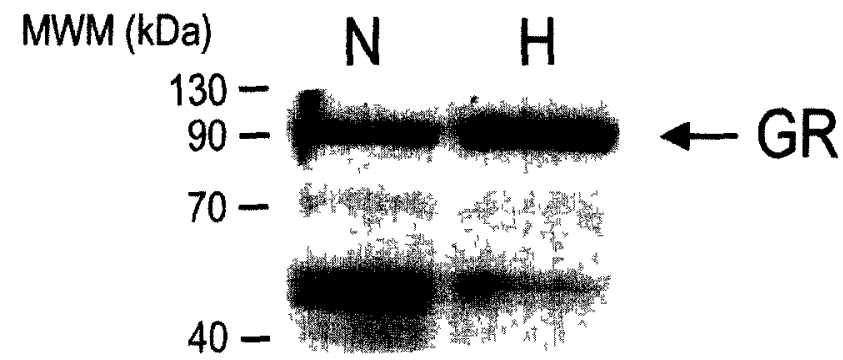

Fig 3 Expression of glucocortucold receptor (GR) in rat hepatocytes kept in normoxic or hypoxic conditions for $6 \mathrm{~h}$ as determined by Western blotting The migration of the molecular weight makers is induated ( $M W M$ ) A representative blot is shown

hypoxia $(8,22)$ Some responses to this condition could be the consequence of decreased cellular ATP concentration Thus we wanted to know whether the observed changes in ASL mRNA levels could be related to the inhibition of oxidative phosphorylation For this purpose hepatocytes, cultured in the presence of $1 \mu \mathrm{M}$ tr1amcinolone, were treated independently with two inhibitors of mitochondrial respiration, dzide and dinitrophenol (DNP), at concentrations previously demonstrated to reduce ATP levels in cultured hepatocytes (8) As shown in Fig 4, treatment for 4 h with either dzide or DNP resulted in a significant reduction in ASL mRNA levels $(65 \%$ and $50 \%$ reduction, respectively) and the concomitant induction of GLUT-1 mRNA as described (23)

Studies performed on the regulation of different genes by hypoxia indicate that this condition is primarily sensed by a distinct mechanism, which is independent of changes in ATP levels $(3,24)$ Although the precise nature of the mammalian oxygen sensor remains elusive, the ability of certain transition metals, such as $\mathrm{Co}^{2+}$, to mimic the effect of hypoxia on several hypoxia-responding genes suggests the implication of a heme-based sensor $(3,24)$ We have tested this hypothesis on the expression of ASL mRNA in hepatocytes cultured in the presence of $1 \mu \mathrm{M}$ triamcinolone When cells were treated for $4 \mathrm{~h}$ with $50 \mu \mathrm{M} \mathrm{CoCl}_{2}$, a concentration previously shown to be non-toxic for rat hepatocyte cultures (25), a reduction in ASL mRNA levels was observed (Fig 4) The concomitant induction of GLUT-1 mRNA in cells treated with $\mathrm{CoCl}_{2}$ was consistent with previous reports (23)

Several lines of evidence have shown that changes in the intracellular levels of reactive oxygen species (ROS) occur during hypoxia, and that ROS could be implcated in the signaling of the hypoxic stimulus $(3,24,26,27)$ We have tested whether alterations in the cellular ROS levels could affect hepatocyte ASL mRNA contents Treatment of cultured hepatocytes under normoxic conditions with the $\mathrm{H}_{2} \mathrm{O}_{2}$ degrading enzyme catalase ( $2000 \mathrm{units} / \mathrm{ml}$ for $6 \mathrm{~h}$ ) did not affect ASL mRNA levels (not shown) Similarly the addition of desferrioxamine (DFO) (180 $\mu \mathrm{M}$ for $6 \mathrm{~h}$ ), an iron chelator capable of preventing hydroxyl radical production (28), resulted in no changes in ASL mRNA levels, either in normoxia or hypoxia (not shown) With similar results the opposite intervention, namely the induction of intracellular $\mathrm{H}_{2} \mathrm{O}_{2}$ production by treatment with menadione dt concentrations which did not compromise ATP levels $(50 \mu \mathrm{M}$ for $6 \mathrm{~h}$ ) $(29,30)$ produced no changes in ASL expression (not shown)

\section{Mechanism of hypoxia downegulation of ASL mRNA levels}

Hypoxia control of gene expression can be accomplished at the transcriptional and postranscriptional levels (24) In order to study the mechanisms involved in hypoxia-mediated downregulation of ASL express1on, we measured ASL mRNA levels in not moxic and hypoxic cultures of hepatocytes in the presence or $a b$ sence of the transcriptional inhibitor actinomycin $\mathrm{D}$ ( 5 $\mu \mathrm{g} / \mathrm{ml}$ ) As shown in Fig $5 \mathrm{~A}$, in the absence of actinomycin $\mathrm{D}$, hypoxia induced the expected time-dependent reduction in ASL mRNA levels However, when the same experiment was performed in the piesence of actınomycin D, the effect of hypoxia was not observed (Fig $5 \mathrm{~B}$ ) After $7 \mathrm{~h}$ of actunomycin D treatment, ASL mRNA levels in both normoxic and hypoxic cultures

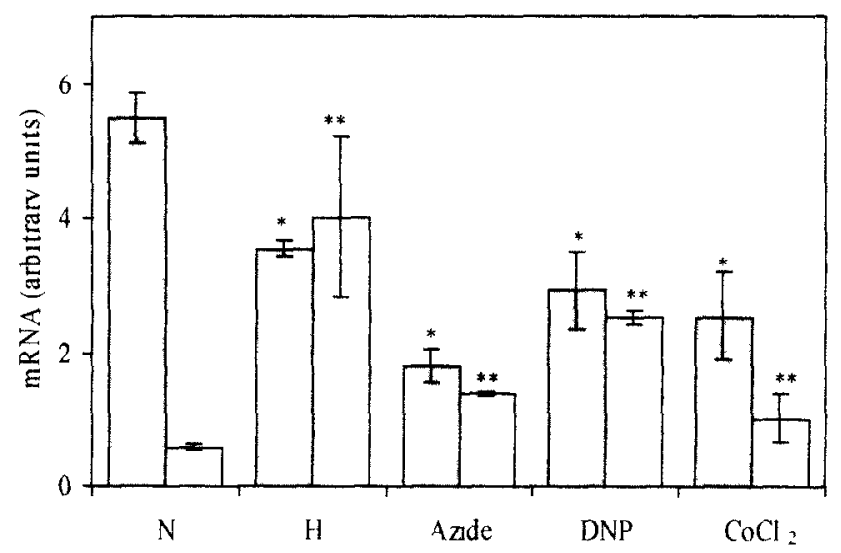

Fig 4 Expression of ASL (closed bais) and GLUT-1 (open bars) $m R N A s$ in rat hepatoc vtes kept for $4 \mathrm{~h}$ in normoxia $(N)$ hvpoxia (H) or in normoxlc conditions plus 2 $m M$ azide. $50 \mu M$ DNP or $50 \mu M \mathrm{CoCl}_{2}$ One astertsk indicates $\mathrm{p}<005 \mathrm{w}$ th respect to the $A S L$ inRNA value $m$ normoxia, two asterisks indicate $\mathrm{p}<005$ with lespect to the GLUT-1 mRNA value in normoxia 
-Actinomycin D

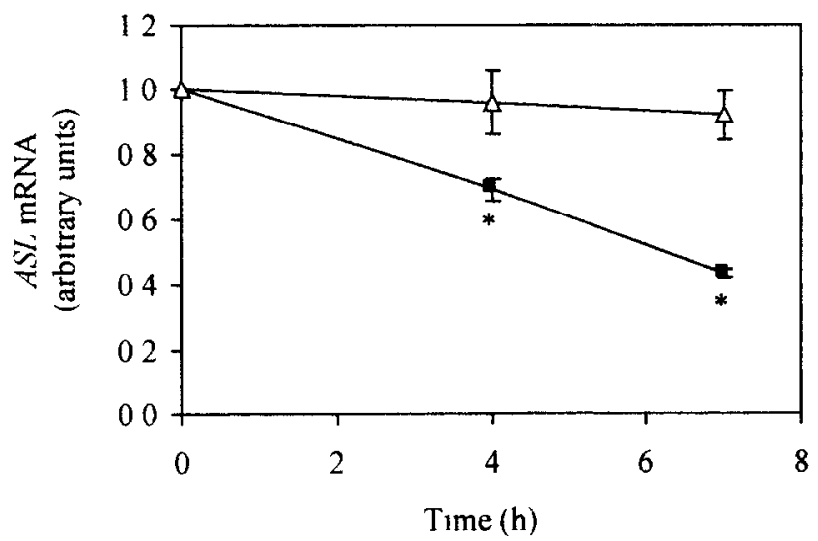

B

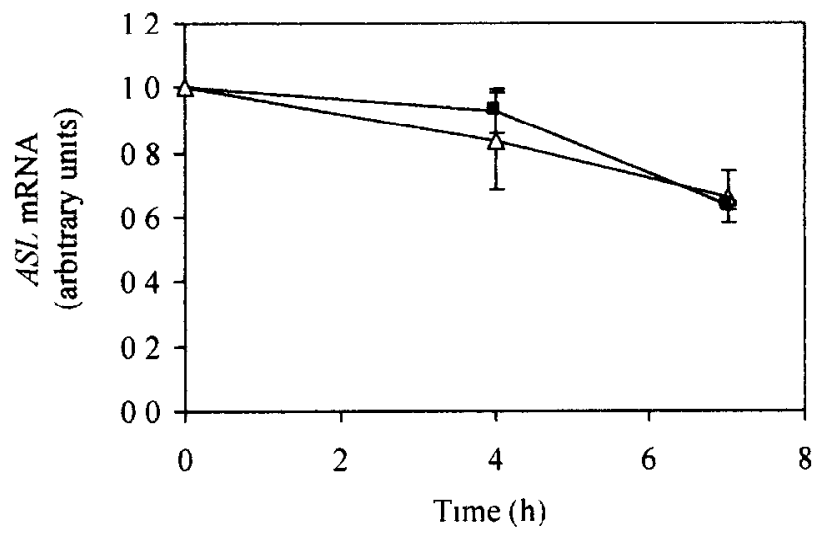

Fig 5 Rat hepatocytes were incubated in normoxic (open triangles) or hypoxic (closed squares) conditions in the absence $(A)$ or presence $(B)$ of $5 \mu \mathrm{g} / \mathrm{ml}$ of the transcriptional inhibutor actinomycin $D$ ASL $m R N A$ levels were quantitated by Northern blotting at different time points Asterisks indicate $\mathrm{p}<005$ with respect to normoxic values

were similarly reduced to $60 \%$ of the levcls found at $t=$ 0 (Fig 5B), indicatıng that ASL mRNA decay was not affected by hypoxia

\section{Discussion}

Searching for genes whose expression could be modulated in rat hepatocytes by hypoxia we have identified an mRNA corresponding to the urea cycle enzyme ASL as being downregulated by low oxygen levels ASL is the fourth enzyme of the urea cycle and, although it is not a rate-controlling enzyme, plays a role in ammonia detoxification and in arginıne production (31) ASL expression in the liver is not homogeneous, in situ hybridization has shown that the mRNA for ASL is present only in the periportal region of the hepatic parenchyma (32) We have observed that rat hepatocytes kept under hypoxia display reduced ASL mRNA steady-state levels ASL mRNA downregulation seems to be specific and not attributable to a general derangement of cellular metabolism by hypoxia Cellular viability was not compromised under our experimental conditions Furthermore, we could detect the concomitant and strong induction of the glucose transporter glut 1 , a well-characterized hypoxia-responsive gene $(7,23,33)$, indicating that the transcriptional machınery of the cell was operative

In agreement with the remarkably long half-life of the urea cycle enzymes, including ASL, reported to be in the range of 3 to 9 days $(34,35)$, we did not detect a reduction in ASL enzymatic activity in hypoxia in our model of cultured rat hepatocytes The rate of degradation of a protein can only be determined if steadystate conditions can be maintained for a period at least 2-3 tımes longer than the expected half-life, and this was not possible in our experimental model Our observation suggests that chronic differences in oxygen avallability, such as those observed across the hepatic parenchyma, rather than acute hypoxia, are more likely to modulate ASL expression

ASL expression in liver is under hormonal control, this is mediated by the positive effects of glucagon and glucocorticoids, which display a cumulative effect when added in combination $(10,36)$ We have examined whether hypoxia could modulate the hormonal-dependent induction of ASL expression Our results indicate that hypoxia was capable of counteracting the effects of both the glucocorticold triamcinolone and the cAMP inducing agent forskolin, when added alone or in combination We have addressed the possibility of an unspecific interference of hypoxia with the cellular responses to glucocorticords through the impairment of GR expression Conversely, our results show that GR levels in hepatocytes kept in hypoxic conditions were upregulated This is, to our knowledge, the first description of GR induction by hypoxia in hepatic cells, although a similar effect had already been reported in cultured human renal cortex epithelial cells (37) Regardıng cAMP signalıng in hypoxıa, proteın k1nase A activity has been shown to be decreased in PC12 cells in hypoxia, however, this effect was observed after longer incubation times than those in which we observed ASL mRNA downregulation by hypoxia in the presence of forskolin (38) These observations suggest that the different oxygen tensions present across the hepatic parenchyma could modulate ASL responses to the two main hormones known to regulate its expression

Sensing oxygen levels in bacteria and yeast have been well characterized In these organisms the impli- 
cation of heme proteins is central to this process (24) In mammalian cells a similar system is thought to participate in oxygen sensing This has been demonstrated by several lines of evidence, which include the ability of certain transition metals to mimic the effect of hypoxia on gene expression (3) Transition metals such as $\mathrm{Co}^{2+}$ could substitute for 1ron in the heme proteins and lock the heme group in the "deoxy" conformation Mimicry of hypoxid by $\mathrm{CoCl}_{2}$ has been reported for other hepatic genes which are downregulated by this condition, such as phosphoenolpyruvate carboxykinase (PCK-1) (25) and methionine adenosyltransferase (8) Our observation of $\Lambda \mathrm{SL}$ mRNA downregulation by $\mathrm{CoCl}_{2}$ treatment suggests that a heme-based sensor could participate in this response

One of the major consequences of hypoxia is the inhibition of oxidative phosphorylation and the concomitant decrease in mitochondrial ATP production For some hypoxia-responsive genes, such as erythropoletin, their response to this condition is not dependent on the limitation of mitochondrial metabolism (39) However, other genes modulated by hypoxia are responsive to both the reduction in oxygen levels per se and the attendant inhibition of oxidative phosphoryldtion The best-characterized example of this dual control by hypoxia is the expression of the glucose transporter GLUT-1 $(23,33)$ Our data obtained in primaiy cultured hepatocytes confirm the previous observations made for glutl expression in transformed or immortalized cell lines, and suggest that ASL could partıcipate in this dual mechanısm for hypoxia sensing

Hypoxid signaling has been linked to changes in intracellular ROS levels Enhanced and diminished ROS production have been reported to occur durıng hypoxia, and both conditions have been proposed to convey signals to the cell nucleus capable of modulating gene expression (40) In our hands ASL mRNA levels were not sensitive to any modification in cellular ROS Perhaps other signaling systems such as protein phosphorylation/dephosphorylation, which are also modulated by hypoxia $(41-43)$, could be implicated in the regulation of ASL expression, however, this remains to be examined

Gene transcription and mRNA stability can be affected by oxygen concentration (24) Our data show that hypoxia regulates ASL expression at the transcriptional level This is demonstrated by the lack of effect of hypoxia on ASL mRNA levels when cellular tıanscription was blocked by actınomycin D treatment Consequently, the decay of ASL mRNA in hepatocytes treated with actinomycin $\mathrm{D}$ was the same under normoxic and hypoxic conditions It is known that induction of ASL expression by glucocorticonds and cAMP in hepatocytes is mainly achieved at the transcriptional level $(10,44)$ The ability of hypoxia to inhibit the effect of these agents strongly suggests that this condition is probably acting at the level of ASL gene transcription In this regard, it has recently been reported that hypoxia inhibition of glucagon-1nduced PCK 1 expression in rat hepatocytes is mediated at the promoter level through the interaction of two putative cAMP-responsive elements (45)

In summary, our results show that the expression of ASL can be downregulated by low oxygen levels in cultured rat hepatocytes We have shown that hypoxid can limit the response of this gene to the two hormonal signals which are central to the regulation of this gene Hence, this cellular iesponse of ASL to reduced oxygen avalability could participdte in the peripoital expression of this enzyme

\section{Acknowledgements}

This work was supported by grants from the Plan Nacional de I+D (SAF 98/0132 and SAF 99/0038), and by a grant from Europharma and Knoll MUL is a fellow of the Fundación Renal Iñigo Alvarez de Toledo MVC and ERGT are Fellows of the Univer sidad de Navarra LT was supported in part by the Generditat Valenciana (Grant POST98-VS-23-132)

The technical support of Fstefeníd Fernández is acknowledged

\section{References}

1 Jungermann $\mathrm{K}$ Katz $\mathrm{N}$ Functional specialization of different hepatocyte populations Physiol Rev 19896970864

2 Jungermann $\mathrm{K}$ Kietzmann $\mathrm{T}$ Zonation of parenchymal and nonparencymal metabolism in liver Annu Rev Nutr 1996, 16 $179-203$

3 Ebert BJ, Bunn HF Regulation of the erythtopoietın gene Blood 199994186477

4 Shweikı D Itın A Sotter D Keshet E Vascular endothelıal giowth factor induced by hypoxia-initlated anglogeness Natue 1992,35984345

5 Semenza GL Jang BH, Leung SW Passantino R Concoudet JP Marre $P$ Gillongo A Hypoxia response elements in the aldolase A enolase 1 and lactate dehydrogenase $A$ gene promoters contan essential binding stes for hypoxai-inducible tactor I I Biol Chem $1996271 \quad 32529 \quad 37$

6 Czyzyk-Kızeska MF, Fuinat 1 BA Lawson EE Milhorn DE Hypoxid incieases tatc of transcription and stability of tyiosine hydroxylase mRNA in pheochromocytoma (PC12) cell, J Brol Chem 19942697604

7 Bashan N, Burdett E Harinder SH Klip A Regulation of glucose transpont and GLUT1 glucose tiansproter expression by $\mathrm{O}_{2}$ in muscle cells in culture Am J Physiol 1992 262 C682 90)

8 Avild MA Carietero MV Rodriguez EN Mato JM Regulation by hypoxid of methonme adenosyltransterase gene expression in 1at hepatocytes Costroenterology $1998 \quad 114 \quad 364 \quad 71$

9 Lrang $P$ Pardee $A B$ Dilleiental display of cukalyotic messenger RNA by mean of the polymerase chan reaction suence 1992 25796771

10 Morrs SM Regulation of enzymes of the urea and argmine yynthess Annu Rer Nutr 19921281101 
11 Velasco JA, Avila MA, Notario V The product of the $c p h$ oncogene is a truncated, nucleotide-binding protein that enhances cellular survival to stress Oncogene 1999, 18 689-701

12 Torres L, Garcia-Trevıjano ER, Rodinguez JA, Carretero MV, Bustos M, Fernandez E, et al Induction of TIMP-1 expression in rat hepatic stellate cells and hepatocytes a new role for homocysteine in liver fibrosis Biochim B1ophys Acta 1999, 1455 1222

13 Hamon GH, Cameron GN The EMBL data library Nucleic Acid Res 1986, 14 5-10

14 Bilofsky HS, Burks C The GeneBank data bank Nucleic Acid Res 1988, 16 1861-4

15 Pearson WR, Lipmann DJ Improved tools for biological sequence comparison Proc Natl Acad Sci USA 1988, 85 2444-8

16 Chomczynskı P, Sacchı N Single-step method of RNA isolation by acid guanidinium thiocyanate-phenol-chloroform extraction Anal B1ochem 1987, 162 156-9

17 Tomlison S, Westall RG Argınınosuccinic acıduria Argınınosuccinase and arginase in human blood cells Clin Sc1 1964, 26261 9

18 Bradford MM A rapid and sensitive method for the quantitation of microgram quantities of protein utilizing the principle of protein dye binding Anal Biochem 1975, 72 248-54

19 Kawamoto S, Kaneko T, Mizukı N, Oshuga A, Fukushıma J, Amaya $Y$, et al Molecular cloning and nucleotide sequence of the rat brain argininosuccinate lyase cDNA with an extremely long 5'-untranslated sequence evidence for the identity of the brain and liver enzymes Brain Res Mol Brain Res 1989, 5235 41

20 Husson A, Renouf S, Fairand A, Buquet C, Benamar M, Vaillant $\mathrm{R}$ Expression of arginınosuccinate lyase mRNA in foetal hepatocytes Eur J Biochem 1990, 192 677-81

21 Caron JM Induction of albumin gene transcription in hepatocytes by extracellular matrix proteins Mol Cell Biol 1990, 10 $1239-43$

22 Aw TY, Jones DP ATP concentration gradients in cytosol of liver cells during hypoxia Am J Physiol 1985, 249 C385-92

23 Behrooz A, Ismall-Beig1 F Dual control of glutl glucose transporter gene expression by hypoxia and by inhibition of oxidative phosphorylation J Biol Chem 1997, 272 5555-62

24 Bunn HF, Poyton RO Oxygen sensing and molecular adaptation to hypoxia Physiol Rev 1996, $76839-85$

25 Kietzmann T, Schmidt H, Probst I, Jungermann K Modulation of the glucagon-dependent activation of phosphoenolpyruvate carboxykinase gene by oxygen in rat hepatocyte cultures FEBS Lett 1992, 311 251-5

26 Ehleben W, Bollıng B, Merten E, Porwol T, Strohmaier AR, Aker $\mathrm{H}$ Cytochromes and oxygen radicals as putative members of the oxygen sensing pathway Resp Physiol 1998, 114 25-36

27 Chandel NS, Scott Budinger GR, Choe SH, Schumacker PT Cellular respiration during hypoxia J Bıol Chem 1997, 272 1880816

28 Richardson DR, Ponka P The molecular mechanisms of the metabolism and transport in normal and neoplastic cells Biochim Biophys Acta 1997, $1331 \quad 1-40$

29 Stone V, Johnson GD, Wilton JC, Coleman R, Chipman JK Effect of oxidative stress and disruption of $\mathrm{Ca}^{2+}$ homeostasis on hepatocyte canalicular function in vitro Blochem Pharmacol $1994,47 \quad 625-32$
30 Fandrey J, Frede S, Jelkmann W Role of peroxide in hypoxiainduced erythropoietin production B1ochem J 1994, 303 50710

31 Jackson MJ, Beaudel AL, O'Brien WE Mammalıan urea cycle enzymes Annu Rev Genet 1986, 20 431-64

32 Dingemanse MA, De Jonge WJ, De Boer PAJ, Morı M, Lamers WH, Moorman AFM Development of the ornithine cycle in rat liver zonation of a metabolic pathway Hepatology 1996, 24 407-11

33 Ebert BL, Firth JD, Ratcliffe PJ Hypoxia and mitochondrial inhibitors regulate expression of glucose transporter-1 via distinct c1s-acting sequences J Biol Chem 1995, 270 29083-9

34 Grisolia S, Timoneda J, Hernandez-Yago J, Soler J, De Arriaga $\mathrm{MD}$, Wallace $\mathrm{R}$ Intracellular degradation of mitochondrial enzymes Acta Biol Med Germ 1981, 40 1407-18

35 Ampola MG The urea cycle enzymes and defects In Arias IM, Boyer JL, Fausto N, Jakoby WB, Schachter DA, Shafritz DA, editors The Liver Biology and Pathobiology, 3rd ed New York Raven, 1994 p 365-77

36 Nebes VL, Morris SM Jr Regulation of messenger rıbonucleıc acid levels for five urea cycle enzymes in cultured rat hepatocytes Requirement for cyclic adenosine monophosphate, glucocort1coids, and ongoing protein synthesis Mol Endocrinol 1988, 2 $444-51$

37 Jenq $W$, Rabb $H$, Wahe $M$, Ramırez $G$ Hypoxic effects on the expression of mineralocorticond and glucocorticoid receptors in human renal cortex epithelial cells B1ochem Biophys Res Commun 1996, 2184448

38 Beitner-Johnson D, Leibold J, Millhorn DE Hypoxia regulates the camp-and $\mathrm{Ca}^{2+} /$ calmodulin signaling systems in $\mathrm{PC} 12$ cells B1ochem B1ophys Res Commun 1998, 241 61-6

39 Goldberg MA, Dunnıng SP, Bunn HF Regulation of erythroporetin gene evidence that the oxygen sensor is a heme protein Science 242 1412-5

40 Zhu H, Bunn HF Oxygen sensing and signaling impact on the regulation of physiologically important genes Resp Physıol 1999, $\begin{array}{lll}115 & 239 & -47\end{array}$

41 Conrad PW, Freeman TL, Beitner-Johnsosn D, Millhorn DE EPAS1 trans-activation during hypoxıa requires p42/p44 MAPK J Biol Chem 274, 33709-13

42 Landeroute KR, Mendonca HL, Calaoagan JM, Knapp AM, Giaccia AJ, Stork PJ Mitogen-activated protein kinase phosphatase-1 (MKP-1) expression is induced by low oxygen conditions found in solid tumor microenvironments A candidate MKP for the inactivation of hypoxia-inducible stress-activated protein kinase/c-Jun N-terminal protein kinase actıvity J Biol Chem 1999, 274 12890-7

43 Kuetzmann T, Jungermann K Modulation by oxygen of zonal gene expression in liver studied in primary rat hepatocyte cultures Cell B1ol Toxicol 1997, 13 243-55

44 Renouf S, Buquet C, Fairand A, Benamar M, Husson A Changes in levels of arginınosuccinate lyase mRNA during induction by glucagon and cyclic AMP in cultured foetal-rat hepatocytes B1ochem J 1993, 291 609-13

45 Bratke J, Kıetzmann T, Jungermann $\mathrm{K}$ Identification of an oxygen-responsive element in the S'-flanking sequence of the rat cytosolic phosphoenolpyruvate carboxykinase-1 gene, modulating its glucagon-dependent activation B1ochem J 1999, 339 563- 